\title{
Effectiveness of the Use of Dexamethasone in Treatment of Coronavirus Infections: A Systematic Review
}

\author{
Muhammad Ardi Munir ${ }^{1,2 *}$, Sarifuddin Sarifuddin ${ }^{3}$, Amirah Basry $^{4}$ (D) , Christin Rony Nayoan ${ }^{5}$, Astri Hardiyanti ${ }^{6}$, Asep Dwitama Cyio ${ }^{6}$ \\ ${ }^{1}$ Department of Bioethics, Humanities, and Social Health Science, Faculty of Medicine, Tadulako University, Palu, Indonesia; \\ ${ }^{2}$ Department of Orthopaedic and Traumatology, Faculty of Medicine, Tadulako University, Palu, Indonesia; ${ }^{3}$ Department of \\ Pulmonology and Respiratory Medicine, Faculty of Medicine, Tadulako University, Palu, Indonesia; ${ }^{4}$ Department of Biochemistry, \\ Faculty of Medicine, Tadulako University, Palu, Indonesia; ${ }^{5}$ Department of Pharmacology, Faculty of Medicine, Tadulako \\ University, Palu, Indonesia; ${ }^{6}$ Medical Profession Program, Faculty of Medicine, Tadulako University, Palu, Indonesia
}

Edited by: Mirko Spirosk Citation: Munir MA, Sarifuddin S, Basry A, Nayoan CR, Hardiyanti A, Cyio AD. Effectiveness of the Use of Dexamethasone in Treatment of Coronavirus Infections: A Systematic Review. Open Access Maced J Med Sci. 2020 Nov 16; 8(T1):518-521. https://doi.org/10.3889/oamjms.2020.5489 Keywords: Effectiveness; Coronavirus disease-19; Dexamethasone; Treatmen *Correspondence: Muhammad Ardi Munir, Departmen Medicics, Humanities and Social Science, Faculty of Indonesia. E-mail: ardimuniruntad@gmail.com Received: 29-Sep-2020
Revised: 02-Nov-2020 Accepted: 06-Nov-2020
Copyright: $\odot 2020$ Muhammad Ardi Munir, Sarifuddin Sarifuddin, Amirah Basry, Christin Rony Nayoan, Astri Hardiyanti, Asep Dwitama Cyi Funding: This study was supported by the LPPM of Tadulako University. Publication of this article was

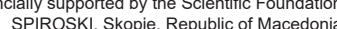
Competing Interests: The authors have declared that no Open Access: This is an open-access article distributed under the terms of the Creative Commons AttributionNonCommercial 4.0 International License (CC BY-NC 4.0)

\begin{abstract}
BACKGROUND: WHO declared the coronavirus disease (COVID)-19 outbreaks as a worldwide pandemic in March 2020. More than $1,500,000$ confirmed cases have been diagnosed in more than 130 countries and regions, estimated to cause 93,000 deaths so far recorded on April 10, 2020. There is no vaccine or antiviral treatment for coronavirus. METHODS: The literature sources from the research were obtained by searching for national and internationa journals. The journal is indexed in Google Scholar, PubMed, Science Direct, e-books, and others. Five journals were obtained, including a literature review, systematic review, and randomized controlled trials (RCT) discussing the use of dexamethasone in COVID-19 therapy, Middle East respiratory syndrome, and severe acute respiratory syndrome. RESULTS: A study from Oxford University compared 2100 COVID-19 patients who received low and moderate potential dexamethasone at a dose of $6 \mathrm{mg} /$ day for 10 days with 4300 COVID-19 patients who only received standard treatment for coronavirus infection. The results obtained in patients using ventilator mortality decreased from $40 \%$ to $28 \%$, and patients using oxygen, the mortality rate decreased from $40 \%$ to $20 \%$. The dexamethasone RCT study can reduce the death rate of 1 in 3 COVID-19 patients who received mechanical ventilation therapy and 1 in 5 patients who received oxygen therapy without mechanical ventilation but did not reduce patients' mortality rate who did not receive therapy oxygen.

CONCLUSION: The use of dexamethasone with oxygen therapy and mechanical ventilation can reduce mortality
\end{abstract} patients with COVID-19.

\section{Introduction}

Coronavirus (CoV) is an RNA virus of $120-160$ $\mathrm{nm}$ particulate size. This virus infects mostly wildlife, including bats and camels. CoV is contagious with six types: Alphacoronavirus 229E, alphacoronavirus NL63, OC43 beta CoV, HKU1 beta-CoV, severe acute respiratory syndrome-CoV (SARS-CoV), and Middle East Respiratory CoV Syndrome (Middle East respiratory syndrome [MERS]-CoV) [1], [2].

In December 2019, due to an unknown virus, some patients in Wuhan, Hubei, China, were diagnosed with secondary pneumonia. From December 31, 2019, to January 3, 2020, there was a significant increase in cases marked by 44 cases reported. This disease has spread in separate provinces in China, Thailand, Japan, and South Korea for $<1$ month [3], [4].

The sample studied shows the etiology of a new type of CoV. The name of this disease was originally the 2019 novel CoV (2019-nCoV). The WHO revealed a new name on February 11, 2020, CoV Disease (COVID-19), which was caused by the CoV-2 (SARS-CoV-2) extreme acute respiratory syndrome virus [5], [6].

In March 2020, the WHO proclaimed the COVID-19 epidemic a global pandemic. In more than 130 countries and regions, more than $1,500,000$ confirmed cases are diagnosed, expected to cause 93,000 casualties as recorded on April 10, 2020 [7].

SARS-CoV-2 can cause various symptoms, including fever, fatigue, dry cough, myalgia, and difficulty breathing. There is evidence that SARSCoV-2 variations have been produced from humans by respiratory outlets triggered by cough and sneezing [8]. There is no vaccine or antiviral treatment for CoV. Therefore, it is imperative to determine the treatment plan as soon as possible for the COVID-19 outbreak [9], [10], [11].

Dexamethasone is a corticosteroid preparation. Corticosteroids have an outstanding inhibitory effect on inflammatory factors and are typically used 
as an alternative treatment for viral pneumonia. Glucocorticoids are steroid hormones with antiinflammatory properties that block pro-inflammatory genes encoding cytokine, chemokine, cellular adhesion molecules, inflammatory enzymes, and inflammatory process receptors [12].

Dexamethasone was shown to be the first drug to prevent CoV deaths in more than 430,000 patients worldwide, based on a randomized controlled clinical trial (randomized controlled trials [RCT]) study in the United Kingdom. Dexamethasone can decrease mortality by around one-third in patients with CoV infection ventilators in these tests [13], [14], [15]. Based on these problems, we are interested in conducting a literature review on the effectiveness of using dexamethasone in the treatment of $\mathrm{CoV}$ infections.

\section{Methods}

This literature uses the method of literature review. Sources from the research were obtained by searching for national and international journals. The journal is indexed in Google Scholar, PubMed, Science Direct, e-books, and others. Five bulletins were obtained, including a literature review, systematic review, and RCT discussing the use of dexamethasone in COVID-19 therapy, MERS, and SARS.

\section{Results}

In a recovery trial study in March 2020 conducted at Oxford University, a RCT tested various potential therapies. The research compares 2100 patients receiving low to moderate potential $6 \mathrm{mg}$ a day dexamethasone for 10 days, with 4300 patients getting normal CoV treatment only. The findings found that dexamethasone had the most extraordinary effect relative to mildly ill people in seriously ill patients who used ventilators. The results of using dexamethasone in patients using a ventilator can reduce the risk of death from $40 \%$ to $28 \%$. Dexamethasone also has an effect on patients taking oxygen therapy but not on the ventilator; an increase in mortality decreased from $40 \%$ to $20 \%$ [16]

Based on studies conducted by Chen et al., corticosteroids were administered to 401 SARS patients, in which there were 152 patients in the critical category. The results showed that corticosteroids reduced mortality and treatment time in acute SARS patients. Dose offered for $<7$ days is low-moderate (to $0.5-1 \mathrm{mg} / \mathrm{kg}$ body weight or equivalent of methylprednisolone) [17].

Built upon the RCT dexamethasone report, the mortality rate was reduced by 1 in 3 COVID-19 patients receiving mechanical ventilation and by 1 in 5 COVID-19 patients receiving oxygen therapy without mechanical ventilation, but mortality rates were not reduced in those without oxygen therapy [18], [19].

Table 1 shows the use of dexamethasone in the preliminary report and some guidelines that have used dexamethasone as a therapy in the treatment of COVID-19.

\section{Discussion}

Since the first study was released in December 2019, COVID-19 has gained worldwide interest because of its similarity to SARS-CoV and MERS-CoV in causing fatal respiratory illnesses and possibly contributing to significant human infections and their economic effects. The use of corticosteroid treatment is still under consideration in patients with SARS and MERS that are close to COVID-19 [24], [25].

Corticosteroid therapy of patients with SARS is used regardless of the early anecdotal knowledge,

Table 1: Using dexamethasone

\begin{tabular}{|c|c|c|c|c|}
\hline References & Year & Drug & Trial and clinical experience & Dosage \\
\hline $\begin{array}{l}\text { Horby Peters [20] } \\
\text {. }\end{array}$ & 2020 & $\begin{array}{l}\text { Dexamethasone } \\
\text { intravenous }\end{array}$ & $\begin{array}{l}\text { A total of } 2104 \text { patients were assigned to receive dexamethasone and } 4321 \text { to receive usual care. Overall, } 482 \\
\text { patients }(22.9 \%) \text { in the dexamethasone group and } 1110 \text { patients }(25.7 \%) \text { in the usual care group died within } 28 \\
\text { days after randomization (age-adjusted rate ratio, } 0.83 ; 95 \% \text { confidence interval }[\mathrm{Cl}], 0.75-0.93 ; \mathrm{p}<0.001) \\
\text { In the dexamethasone group, the incidence of death was lower than that in the usual care group among } \\
\text { patients receiving invasive mechanical ventilation }(29.3 \% \text { vs. } 41.4 \% \text {; rate ratio, } 0.64 ; 95 \% \mathrm{Cl}, 0.51-0.81) \text { and } \\
\text { among those receiving oxygen without invasive mechanical ventilation }(23.3 \% \text { vs. } 26.2 \% \text {; rate ratio, } 0.82 ; 95 \% \\
\mathrm{Cl}, 0.72-0.94) \text { but not among those who were receiving no respiratory support at randomization }(17.8 \% \text { vs. } \\
14.0 \% \text {; rate ratio, } 1.19 ; 95 \% \mathrm{Cl}, 0.91-1.55)\end{array}$ & $\begin{array}{l}6 \mathrm{mg} \text { once daily } \\
\text { for up to } 10 \text { day }\end{array}$ \\
\hline $\begin{array}{l}\text { Guidelines CHKD } \\
\text { [21], [22] }\end{array}$ & 2020 & $\begin{array}{l}\text { Dexamethasone } \\
\text { intravenous and peroral }\end{array}$ & $\begin{array}{l}\text { Dexamethasone should not be used in COVID-19 }(+) \text { patients who are: } \\
\text { a) Otherwise healthy and do not require respiratory support } \\
\text { Dexamethasone should be utilized in COVID-19 }(+) \text { patients with: } \\
\text { a) Respiratory support (oxygen or invasive mechanical ventilation) } \\
\text { b) An underlying condition requiring chronic steroid treatment, steroids should be continued } \\
\text { c) An additional diagnosis where steroid therapy is appropriate }\end{array}$ & $\begin{array}{l}0.15 \mathrm{mg} / \mathrm{kg} \text { once } \\
\text { daily (Max: } 6 \mathrm{mg} \text { ) }\end{array}$ \\
\hline Raymond [23] & 2020 & Dexamethasone & $\begin{array}{l}\text { In the RECOVERY trial, dexamethasone was beneficial for participants treated seven or more days into the } \\
\text { symptomatic phase, with the onset of hypoxemia. Importantly, there was a non-significant trend }(P=0.14) \\
\text { toward possible harm affecting participants without hypoxemia and not on mechanical ventilation. RECOVERY } \\
\text { findings, therefore, support use of dexamethasone only for patients with hypoxemia, not those with milder } \\
\text { disease. The data do not support the use of dexamethasone or other corticosteroids in the outpatient setting }\end{array}$ & $6 \mathrm{mg} / \mathrm{day}$ \\
\hline
\end{tabular}


and it is comparable of patients with acute respiratory distress syndrome (ARDS) to radiological and histologic observations in essential diseases [26], [27]. In March 2003, the proposed high dose glucocorticoids should be used based on Chinese SARS treatment trials if the patient has a fever for more than three days or if radiological reports are indicative. Persistent pulmonary activity or gradual decline In Bronchiolitis obliterans, the radiographic picture with pneumonia and likeness of the histologic features to those of early ARDS in postmortem studies have prompted doctors in china use corticosteroids in combination with ribavirin for the treatment of SARS. In ARDS and particularly in Bronchiolitis obliterans with organizing pneumonia, corticosteroid therapy with ribavirin has been used with some success in the resolution of fever and lung opacities within two weeks [28].

Recovery trials conducted at Oxford University show that at the dose of dexamethasone tested, steroid treatment benefits may outweigh the potential harm posed. This research did not find any remarkable medication side effects. According to Anthonia, a deformed or hyperactive inflammatory reaction in patients with a ventilator leads to morbidity, mortality, and clear viral effects [13].

The corticosteroid partnership in SARS management may be complicated with acute lung injury (ALI)/ARDS. Excessive systemic inflammation has been identified in ARDS and $B$ emission factors may lead to glucosteroid tolerance, which is related to relative adrenal insufficiency and further degradation of ARDS. Use methylprednisolone, which can be used to solve problems by recovering systemically. The present opinion thus indicates that ARDS steroid therapy can only be done on the basis of relative loss due to systemic inflammation and targeted at increasing systemic inflammation. The length of the steroid depends on the inflammatory length. In summary, appropriate advice for ALI/ARDS steroid administration involves the initialization of a sufficient steroid dosage at a time of relative adrenal insufficiency, discussed in terms of steroid application. Steroids need not, however, be delayed until ARDS continues [17], [29], [30].

Corticosteroids will dramatically reduce the concentrations of interleukin (IL)-8, monocyte protein-1, and induced protein-10 from days 5 to 8 after treatment. In further analysis, IL-10, IL-6, and tumor necrose (tumor necrosis factor [TNF]) levels were higher than average before intake. Corticosteroid treatment still decreases IL-10 but not IL-6 and TNF. The data show the benefits of steroid therapy in reducing the lungs' reserve response and protection [28], [31].

They observed that corticosteroids, large doses of 2019-nCoV pneumonia such as secondary infections, long-term complications, and extendedrelease of the virus were likely based on corresponding research. However, severe inflammation and cytokine-related lung injuries can rapidly cause progressive pneumonia in critically ill patients. Doctors of the Chinese Thoracic Community have formed a consensus of experts on pneumonia corticosteroids 2019-nCoV. Under the expert's agreement on the basics of use with corticosteroids to be discussed;(1) The role of corticosteroids in suppressing the production of dysregulated cytokines patient with pneumonia in 2019-ncoV (2) Corticosteroid must be used with caution in a critically diseased patient with pneumonia in 2019ncoV; (3) with hypoxia patients [32].

\section{Conclusion}

The use of dexamethasone with oxygen therapy and mechanical ventilation can reduce mortality patients with COVID-19.

\section{References}

1. Susilo A, Rumende CM, Pitoyo CW, Santoso WD, Yulianti M Herikurniawan $\mathrm{H}$, et al. Coronavirus disease 2019: Tinjauan literatur terkini. JPDI. 2020;7(1):45.

2. Nemati $H$, Ramezani $M$, Najafi F, Sayad B, Nazeri M, Sadeghi M. Evaluation of angiotensin-converting enzyme 2 (ACE2) in COVID-19: A systematic review on all types of studies for epidemiologic, diagnostic, and therapeutic purposes: Angiotensin-converting enzyme 2 (ACE2) in COVID-19. Open Access Maced J Med Sci. 2020;8(1):84-91. https://doi. org/10.3889/oamjms.2020.4763

3. Huang C, Wang Y, Li X, Ren L, Zhao J, Hu Y, et al. Clinical features of patients infected with 2019 novel coronavirus in Wuhan, China. Lancet. 2020;395(10223):497-506. https://doi. org/10.3889/oamjms.2020.4910

4. Sitepu FY, Depari E, Aditama W, Halim R, Isworo A Lumbangaol $\mathrm{BH}$, et al. A survey of the knowledge of surveillance officers and outbreak investigation team toward COVID-19 in North Sumatera Province, Indonesia. Open Access Maced J Med Sci. 2020;8(T1):55-60.

5. Ortiz-Prado E, Simbaña-Rivera K, Gómez-Barreno L, RubioNeira M, Guaman LP, Kyriakidis NC, et al. Clinical, molecular, and epidemiological characterization of the SARS-CoV-2 virus and the coronavirus disease 2019 (COVID-19), a comprehensive literature review. Diagn Microbiol Infect Dis. 2020;98(1):115094. https://doi.org/10.1016/j.diagmicrobio.2020.115094

PMid:32623267

6. Gillespie M, Dincher N, Fazio P, Okorji O, Finkle J, Can A Coronavirus disease 2019 (COVID-19) complicated by spontaneous pneumomediastinum and pneumothorax. Respir Med Case Rep. 2020;31:101232. https://doi.org/10.1016/j. rmcr.2020.101232 PMid:32989414

7. Veronese N, Demurtas J, Yang L, Tonelli R, Barbagallo M, Lopalco $\mathrm{P}$, et al. Use of corticosteroids in coronavirus disease 2019 pneumonia: A systematic review of the literature. Front Med. 2020;7:170. 
8. Yang Z, Liu J, Zhou Y, Zhao X, Zhao Q, Liu J. The effect of corticosteroid treatment on patients with coronavirus infection: $A$ systematic review and meta-analysis. J Infect. 2020;81(1):e1320. https://doi.org/10.1016/j.jinf.2020.03.062

\section{PMid:32283144}

9. Alonso DF, Farina HG. Repurposing of host-based therapeutic agents for the treatment of coronavirus disease 2019 (COVID19): A link between antiviral and anticancer mechanisms? Int J Antimicrob Agents. 2020;56(3):106125. https://doi. org/10.1016/j.jjantimicag.2020.106125 PMid:32739476

10. Gurung AB, Ali MA, Lee J, Farah MA, Al-Anazi KM. Structurebased virtual screening of phytochemicals and repurposing of FDA approved antiviral drugs unravels lead molecules as potential inhibitors of coronavirus 3C-like protease enzyme. J King Saud Univ Sci. 2020;32(6):2845-53. https://doi. org/10.1016/j.jksus.2020.07.007

PMid:32837113

11. Hamid S, Mir MY, Rohela GK. Novel coronavirus disease (COVID-19): A pandemic (epidemiology, pathogenesis and potential therapeutics). New Microbes New Infect. 2020;35:100679. https://doi.org/10.1016/j.nmni.2020.100679

PMid:32322401

12. Cruz-Topete D, Cidlowski JA. One hormone, two actions: Anti-and pro-inflammatory effects of glucocorticoids. Neuroimmunomodulation. 2015;22(1-2):20-32. https://doi. org/10.1159/000362724

PMid:25227506

13. Ledford $\mathrm{H}$. Coronavirus breakthrough: dexamethasone is first drug shown to save lives. Nature. 2020;582(7813):469-9. https://doi.org/10.1038/d41586-020-01824-5 PMid:32546811

14. Abdelraouf $M$, Salah $M$, Waheb M, Elshall A. Suboccipital muscles injection for management of post-dural puncture headache after cesarean delivery: A randomized-controlled trial. Open Access Maced J Med Sci. 2019;7(4):549-52. https://doi. org/10.3889/oamjms.2019.105

PMid:30894910

15. Markovski V. Guide to leading a patient with symptoms of an acute respiratory infection during a coronavirus pandemic (COVID-19). Open Access Maced J Med Sci. 2020;8(T1):97102. https://doi.org/10.3889/oamjms.2020.4848

16. Bhandage SG, Kurki MS, Sachdeva G, Shetty N, Kundu M, Yadav AB. Evaluation of efficacy of peri-operative administration of hydrocortisone and dexamethasone in prevention of postoperative complications in oral and maxillofacial surgeries. Rev Española Cir Oral Maxilofac. 2018;40(4):163-8. https://doi. org/10.1016/j.maxilo.2018.01.001

17. Chen $\mathrm{R}$, Tang $\mathrm{XP}$, Tan SY, Liang $\mathrm{BL}$, Wan ZY, Fang JQ, et al. Treatment of severe acute respiratory syndrome with glucosteroids: The Guangzhou experience. Chest. 2006;129(6):1441-52. https://doi.org/10.1378/chest.129.6.1441 PMid: 16778260

18. Boglione L, Rostagno R, Poletti F, Moglia R, Bianchi B, Esposito M, et al. The proper use of corticosteroids for 2019nCov pneumonia: Towards promising results? J Infect. 2020; 16(29):4781. https://doi.org/10.1016/j.jinf.2020.08.001 PMid:32763262

19. Shang L, Zhao J, Hu Y, Du R, Cao B. On the use of corticosteroids for 2019-nCoV pneumonia. Lancet. 2020;395(10225):683-4. https://doi.org/10.1016/s0140-6736(20)30361-5

PMid:32122468
20. The RECOVERY Collaborative Group, Lim WS, Emberson JR, Mafham M, Bell JL, Linsell L, Staplin N, et al. Dexamethasone in hospitalized patients with covid-19-preliminary report. N Engl J Med. 2020; 382(20):1-11. https://doi.org/10.1056/ nejmoa2021436

PMid:32678530

21. Liu E, Smyth RL, Luo Z, Qaseem A, Mathew JL, Lu Q, et al Rapid advice guidelines for management of children with COVID-19. Ann Transl Med. 2020;8(10):617-7.

PMid:32566554

22. Sarah P, Laura S. CHKD Treatment Guideline for COVID-19 in Children. 2020. p. 1-5. https://www.chkd.org/uploadedFiles/ Documents/COVID-19/CHKD\%20COVID\%2019\%20 treatment\%20guideline.pdf. [Last accessed on 2020 March 20].

23. Johnson R, Vinetz J. Dexamethasone in the management of covid-19. BMJ. 2020:m2648. https://doi.org/10.1136/bmj. $\mathrm{m} 2648$.

24. Horby P, Lim WS, Emberson J, Mafham M, Bell J, Linsell L, et al. Effect of dexamethasone in hospitalized patients with COVID19: Preliminary report. Infect Dis. 2020;263:1-18. https://doi.org /10.1101/2020.06.22.20137273.

25. Arabi YM, Mandourah Y, Al-Hameed F, Sindi AA, Almekhlafi GA, Hussein MA, et al. Corticosteroid therapy for critically ill patients with Middle East respiratory syndrome. Am J Respir Crit Care Med. 2018;197(6):757-67.

PMid:29161116

26. Yam LY, Lau AC, Lai FY, Shung E, Chan J, Wong V. Corticosteroid treatment of severe acute respiratory syndrome in Hong Kong. $J$ Infect. 2007;54(1):28-39. https://doi.org/10.1016/j.jinf.2006.01.005 PMid:16542729

27. So LK, Lau AC, Yam LY, Cheung TM, Poon E, Yung RW, et al. Development of a standard treatment protocol for severe acute respiratory syndrome. Lancet. 2003;361(9369):1615-7. PMid: 12747883

28. Lee N, Hui D, Wu A, Chan P, Cameron P, Joynt GM, et al. A major outbreak of severe acute respiratory syndrome in Hong Kong. N Engl J Med. 2003;348(20):1986-94.

PMid: 12682352

29. Zhong NS, Zeng GQ. Our strategies for fighting severe acute respiratory syndrome (SARS). Am J Respir Crit Care Med. 2003;168(1):7-9. https://doi.org/10.1164/rccm.200305-707oe PMid: 12773318

30. Meduri GU, Tolley EA, Chrousos GP, Stentz F. Prolonged methylprednisolone treatment suppresses systemicinflammation in patients with unresolving acute respiratory distress syndrome: Evidence for inadequate endogenous glucocorticoid secretion and inflammation-induced immune cell resistance to glucocorticoids. Am J Respir Crit Care Med. 2002;165(7):98391. https://doi.org/10.1164/ajrccm.165.7.2106014

PMid: 11934726

31. Peiris J, Chu CM, Cheng VC, Chan KS, Hung IF, Poon LL, et al. Clinical progression and viral load in a community outbreak of coronavirus-associated SARS pneumonia: A prospective study. Lancet. 2003;361(9371):1767-72. https://doi.org/10.1016/ s0140-6736(03)13412-5

PMid: 12781535

32. Jones BM, Ma ES, Peiris JS, Wong PC, Ho JC, Lam B, et al. Prolonged disturbances of in vitro cytokine production in patients with severe acute respiratory syndrome (SARS) treated with ribavirin and steroids. Clin Exp Immunol. 2004;135(3):46773. https://doi.org/10.1111/j.1365-2249.2003.02391.x PMid: 15008980 